\title{
THE EFFECTIVENESS OF EDUCATIONAL GAMES IN MATH LEARNING IN ELEMENTARY SCHOOL
}

\section{Dyah Anungrat Herzamzam}

STKIP Kusuma Negara

\section{Sejarah Artikel}

Diterima 20 Oktober 2018

Disetujui 26 Desember 2018

Diterbitkan 31 Desember 2018

\section{Kata Kunci}

educational games, math, android

\begin{abstract}
Abstrak
The purpose of this research is to know the effectiveness of: (1) android-based educational games and (2) without the games in learning mathematics. This type of research is experimental with Pretest-Posttest design Randomized Control Group Design. In the process of experimentation conducted observations on two groups of learning i.e. experimental group one which was given treatment with android-based educational games in math, learning and a control group with no game. The population of the research was all learners class II SD PB Sudirman Jakarta with samples of learners classes IIA, IIB, and IIC. Research instrument was a matter of addition and subtraction tests that have been tested with Alpha 0.826. Data analysis techniques using Anava followed by Scheffe test.The results showed that: (1) there is a significant difference in effectiveness between learning mathematics using androidbased educational games and without a game in learning addition and subtraction class II SD PB Sudirman Jakarta Timur ( $\mathrm{FH}=6.211>\mathrm{Ft}(0.05)=3.02) ;$ (2) there is a significant difference in the effectiveness of media math learning using android-based educational games and learning in games without fractions, $(\operatorname{sig}(p)=0.005<0.05)$; This shows that the educational learning games mathematics better and effective than without games.

\section{Cara Mengutip}

Herzamzam, D.A. (2018). The Effectiveness of Educational Games in Math Learning in Elementary School. DWIJA CENDEKIA Jurnal Riset Pedagogik, 2 (2), 21-25.

Korespondensi Penulis: 


\section{PENDAHULUAN}

Pendidikan dasar merupakan suatu pijakan awal untuk beranjak pada jenjang pendidikan formal selanjutnya. Pendidikan dasar merupakan kunci pembentukan manusia. Pada pendidikan dasar ada beberapa kunci yang harus diperhatuikan oleh para pendidik. Adapun kunci tersbut adalah penanaman sikap dan perilaku yang sesuai dengan normanorma.

Pembelajaran matematika diajarkan sejak siswa menempuh jenjang pendidikan dasar. Matematika merupakan pelajaran dasar dan fundamental. Sebagian besar siswa memberikan kesan bahwa matematika merupakan momok, menyeramkan, dan menakutkan. Kesan terhadap mata pelajaran matematika tersebut, sebagai pendidik seyogyanya mewujudkan inovasi dalam pembelajaran yang disesuaikan dengan perkembangan zaman.

Dalam mempelajari matematika diperlukan dorongan atau motivasi dari guru, orang tua, dan lingkungan siswa. Pada pembelajaran di kelas, motivasi siswa dapat dibentuk dengan bimbingan guru. Guru memberikan kemudahan belajar bagi siswa. Kemudahan dalam belajar matematika salah satunya dapat mengkaitkan pembelajaran matematika dengan permasalahan nyata yang sering dijumpai siswa dalam kehidupan seharihari. Menurut Chrisnaji Banindra Yudha (2014:p.1) Mata pelajaran matematika di sekolah sangat penting untuk melatih pola pikir siswa. Matematika membentuk pola pikir yang memelajarinya khususnya siswa, diantaranya berpikir logis, analitis, sistematis, kritis dengan penuh kecermatan. Dalam memahami konsep matematika dibutuhkan analisa yang mendalam dari pada ilmu yang lain dan siswa sering mengalami dan menemui kesulitan. Oleh karena itu, dorongan dari motivasi guru sangat diperlukan untuk melatih pola pikirnya.

Guru kurang memotivasi siswa saat proses pembelajaran di kelas. Dasar pertimbangan guru adalah materi pelajaran terlalu banyak dan guru takut apabila semua materi pelajaran tidak dapat disampaikan pada siswa. Ketakutan guru berdampak pada proses pembelajaran yang hanya bertitik tolak pada materi pelajaran. Uraian materi pelajaran diberikan melalui metode drill dan penuntasan materi. Sikap siswa hanya sebagai pendengar, pencatat, dan terkadang tampil di depan kelas untuk menuliskan jawaban atau mempresentasikan hasil jawabannya. Chrisnaji Banindra Yudha (2018:p.14) motivasi sebagai daya pendorong yang besar dalam mempengaruhi seseorang untuk mencapai tujuan yang diinginkan. Oleh karena itu, Oleh karena itu, proses pembelajaran oleh guru haruslah seimbang antara memberikan materi pelajaran yang ada pada kurikulum dan memotivasi siswa untuk memcapai tujuan pembejaran yang diinginkan.

Permasalahan lain yang terjadi adalah tingkat ketakutan terhadap mata pelajaran matematika. Hal ini, dapat dilihat pada saat guru memberikan kesempatan siswa untuk tampil di depan kelas menuliskan, mempresentasikan, atau menempelkan hasil jawaban siswa enggan, siswa tidak mau aktif di kelas karena siswa merasa malu dan selalu dihantui rasa cemas karena takut salah dalam mengerjakan soal matematika. Selain itu, pada setiap sesi pertanyaan yang dilakukan oleh guru pada materi yang belum jelas, semua siswa malu bertanya padahal mereka belum memahami materi. Menurut pengakuan salah satu siswa, kondisi tersebut karena siswa merasa takut pada saat mengikuti pelajaran matematika karena sudah tertanam atau keyakinan diri (self efficacy) pada pemikiran siswa bahwa matematika adalah pelajaran yang sulit untuk dipahami dan dikerjakan. Menurut Chrisnaji Banindra Yudha (2018) self efficacy merupakan keyakinan individu untuk melaksanakan dan menaklukan 
beraneka ragam situasi yang muncul dan dihadapinya. Dengan demikian dengan rendahnya keyakinan mampu menekan kreativitas dan kesuksesan seseorang.

Berdasarkan hasil wawancara peneliti dengan guru kelas II, terungkap bahwa guru lebih sulit memberikan pemahaman konsep matematika. Pemahaman seperti ini sangat menghambat transfer pembelajaran khususnya mata pelajaran matematika. Transfer knowledge yang seperti ini menyebabkan siswa hanya dapat memahami pelajaran tanpa mengetahui peranan matematika untuk kehidupan siswa.

Anak mempunyai tahapan pada perkembangan kognitifnya. Perkembangan kognitif pada anak didik menurut Piaget dalam Berk, L.E (2012: 26), empat tahap perkembangan kognitif. Periode I Kepandaian Sensori, periode II Pikiran Pra-Operasional), periode III Operasi-operasi Berpikir Konkrit, periode IV Operasi-operasi Berpikir Formal. Berdasarkan tahapan perkembangan ini, maka usia anak SD berada pada periode ketiga. Hal ini, menandai suatu titik besar dalam perkembangan kognitif. Pikiran lebih jauh dari sekedar logika. la bersifat fleksibel dan lebih teratur dari sebelumnya. Heruman (2008: 1-2). menambahkan bahwa "dari usia perkembangan kognitif, siswa sekolah dasar masih terikat dengan objek konkret yang dapat ditangkap oleh panca indra Dalam pembelajaran matematika yang abstrak, siswa memerlukan alat bantu berupa media, dan alat peraga yang dapat memperjelas apa yang disampaikan oleh guru sehingga lebih cepat dipahami dan dimengerti oleh siswa". Dyah (2018) menyatakan bahwa, Siswa SD belum mampu berpikir abstrak, pemikiran siswa masih terikat pada halhal konkret sehingga dalam proses pembelajaran sangat perlu diperhatikan pendekatan atau strategi yang sesuai dengan tahap perkembangan kognitif siswa agar siswa memperoleh pengetahuan dengan lebih baik.
Dari uraian di atas, maka siswa SD dari sisi perkembangan kognitif atau intelektual masih berada pada tahap pemikiran operasional konkret. Siswa SD belum mampu berpikir abstrak, pemikiran siswa masih terikat pada hal-hal konkret sehingga dalam proses pembelajaran sangat perlu diperhatikan pendekatan atau strategi yang sesuai dengan tahap perkembangan kognitif siswa agar siswa memperoleh pengetahuan dengan lebih baik.

Pembelajaran seharusnya dikemas secara efektif dan menyenangkan. Guru seyogyanya dapat menyajikan pembelajaran menggunakan strategi pembelajaran yang efektif dan efisien, sesuai dengan kurikulum dan pola pikir siswa yang belajar. Untuk itu, menurut Heruman (2008: 3), pembelajaran matematika di sekolah dasar harus melalui langkah-langkah yang ditekankan pada konsep-konsep matematika, yaitu: (1) Penanaman konsep dasar, yaitu pembelajaran suatu konsep baru matematika kepada siswa yang belum pernah diberikan sebelumnya. Pembelajaran penanaman konsep dasar merupakan jembatan yang harus dapat menghubungkan kemampuan kognitif siswa yang konkret dengan konsep baru matematika yang abstrak. Dalam kegiatan ini, media atau alat peraga diharapkan dapat digunakan untuk membantu kemampuan pola pikir siswa. (2) Pemahaman konsep, pembelajaran lanjutan dari pemahaman konsep, yang bertujuan agar siswa lebih memahami suatu konsep matematika. Konsep jenis ini akan mudah dipahami oleh siswa apabila mereka menguasai konsep prasyaratnya, yaitu konsep dasar. (3) Pembinaan keterampilan, yaitu pembelajaran yang bertujuan agar siswa lebih terampil dalam menggunakan berbagai konsep matematika. Dengan adanya pembinaan keterampilan terhadap konsep-konsep ini diharapkan proses pembelajaran matematika dapat mengkaji isu-isu tentang kurangnya keterampilan berhitung.

Menurut Nitko dan Brookhart (2007: p.18), "instruction is the proccess you use 
to provide students with the conditions that help them achieve the learning targets". Makna pendapat tersebut adalah guru sebagai fasilitator harus mampu mengorganisir semua unsur pembelajaran dan mengarahkannya pada suasana yang memungkinkan seorang siswa untuk belajar, sehingga kompetensi yang diharapkan dapat tercapai.

Pembelajaran dapat diterima dengan baik oleh siswa. Hal tersebut dapat diberikan oleh guru yang memiliki kreatifitas dalam menerapkan metode, pendekatan, strategi, dan lainnya. Penerapannya sangat tepat pada pelajaran yang biasanya dianggap sulit yaitu matematika. Dalam matematika terdapat banyak rumus, hal yang abstrak, keterkaitan pola hubungan, yang harus dihadapi siswa. Oleh karena itu, dalam memberikan matematika yang menyangkut pola hubungan tersebut melalui tahapan (1) penanaman konsep dasar, (2) pemahaman konsep, dan (3) pembinaan keterampilan. Hal tersebut, diharapkan sebagai pemicu dalam mempermudah memahami matematika dan mengubah pola pikir yang negatif tentang matematika.

Pada dasarnya manusia mempunyai sifat ingin tahu. Sifat ini penting dalam proses perkembangan anak. Karena dengan sifat ingin tahu inilah orang berusaha untuk memperoleh sesuatu yang belum diketahui. Salah satu cara untuk mengetahuinya yaitu dengan cara belajar. Dari uraian belajar dalam pengertian belajar diatas, intinnya adalah melalui belajar siswa atau orang dapat berubah tingkah lakunnya.

Belajar matematika adalah suatu aktivitas mental untuk memahami arti dan hubungan-hubungan serta simbol-simbol, kemudian diterapkannya pada situasi nyata Hamzah B. Uno (2009: p.130). Menurut pendapat Schonfeld (Hamzah B. Uno 2009: p.130), mengungkapkan bahwa belajar matematika berkaitan dengan apa dan bagaimana menggunakannya dalam membuat keputusan untuk memecahkan masalah.

Pembelajaran matematika memiliki 5 karakteristik menurut Gravemeijer
(Zulkardi 2002 : p.2) diantaranya: (1) Penggunaan konteks: proses pembelajaran diawali dengan keterlibatan siswa dalam masalah kontekstual. (2) Instrumen vertikal : konsep atau ide matematika direkontruksi oleh siswa melalui model-model instrumen vertikal, yang bergerak dari prosedur informal kebentuk formal. (3) Kontribusi siswa : siswa aktif mengkontruksi sendiri bahanbahan matematika berdasarkan fasilitas dengan lingkungan belajar yang disediakan guru, secara aktif menyeleseikan soal dengan cara masingmasing. (4) Kegiatan interaktif : kegiatan belajar bersifat interaktif, yang memungkinkan terjadi komunikasi dan negosiasi antar siswa. (5) Keterkaitan topik : pembelajaran suatu bahan matematika terkait dengan berbagai topik matematika terintegrasi. Dari pendapat diatas dapat disimpulkan bahwa pembelajaran matematika dapat bermakna apabila siswa yang menemukan sendiri konsep yang telah dipelajari. Belajar matematika siswa memahami tentang konsep-konsep dan prinsip-prinsip yang abstrak dan disusun secara hirarkis.

Tujuan pembelajaran matematika adalah melatih dan menumbuhkan cara berpikir secara sistematis, logis, kritis, kreatif, dan konsisten serta mengambangkan sikap gigih dan percaya diri sesuai dalam menyeleseikan masalah (BSNP, 2006: p.148). Hal ini menunjukkan bahwa matematika adalah pelajaran yang penting dan perlu diberikan pada semua siswa mulai dari sekolah dasar.

Pendapat lain menurut Haylock dan Thangata (2007: p.3), mengatakan bahwa "the aims of mathematics teaching can be categorized under five heading; utarinilan, applications, tranferable skills, aesthetics and epistemological", artinya bahwa tujuan dari pengajaran matematika adalah bermanfaat, dapat digunakan transfer keahlian, estetika, dan epistimologi.

Heruman (2008: p.4), bahwa "dalam pembelajaran matematika tingkat SD diharapkan terjadi reinvention (penemuan 
kembali)". Penemuan kembali adalah menemukan cara penyeleseian secara informaldalam pembelajaran dikelas. Selain penemuan, dalam pembelajaran matematika SD juga dengan belajar bermakna dimana siswa menghubungkan atau mengkaitkan informasi pada pengetahuan berupa konsep-konsep yang telah dimilikinya. Dalam belajar matematika, siswa membangun pengetahuan sendiri dan guru sebagai fasilitator.

Asri C. Budiningsih (2012: p.58), mengungkapkan bahwa kegiatan belajar dipandang dari segi prosesnya dari pada dipandang dari segi perolehan pengetahuan dari fakta yang terlepas. Proses tersebut berupa membangun dan restrukturisasi pengetahuan dan ketrampilan guna peningkatan diri individu dalam jaringan yang kompleks konsistensi konseptual.

Pada uraian diatas menunjukkan bahwa, guru dalam mengajar matematika seharusnya melalui proses belajar yang terencana dan berpola. Dalam merencanakan proses pembelajaran sekurang-kurangnya meliputi tujuan pencapaian, materi pembelajaran, siswa, media/alat pembelajaran, metode/pendekatan/strategi yang akan digunakan, dan waktu pembelajaran. Hal ini tanpa mengkesampingkan faktor yang lain. Kualitas dan produktivitas pembelajaran akan tampak ketika siswa mencapai tujuan pembelajaran yang ditetapkan, hal ini terkait dengan model/pendekatan/strategi yang dilaksanakan guru. Menurut Chrisnaji Banindra Yudha (2018), Media mempunyai peran penting dalam pembelajaran matematika, media pembelajaran membantu guru dalam mengatur proses pembelajarannya serta penggunaan waktu di kelas dengan efektif dan efisien.

Android merupakan sistem operasi untuk telephone seluler yang berbasis Linux. Android menyediakan platform terbuka bagi para pengembang aplikasi mereka sendiri untuk digunakan oleh bermacam peranti bergerak. Kemudian untuk mengembangkan Android, dibentuklah Open Handset Alliance, konsorsium dari 34 perusahaan peranti keras, peranti lunak, dan telekomunikasi, termasuk Google, HTC, Intel, Motorola, Qualcomm, T-Mobile, dan Nvidia. Komputer wahana (2012). Salah satu dari kelebihan Android sendiri adalah dari segi macam kategori; aplikasi, social, hiburan dan juga permainan dan sebagainya. Para Developer bisa mengembangkan sendiri aplikasi sesuai dengan keinginan mereka sendiri dengan mengunakan Software Development Kit (SDK) yang google telah menditribusikannya untuk umum. Karena Android termasuk OS yang cepat berevolusi karena berbasis open source dengan semakin bertambahnya aplikasi yang di sediakan oleh google sendiri maupun oleh Developer sendiri yang nantinya ini bisa di unduh lewat Google Play Store.

Sugeng Purwantoro, Heni Rahmawati dan Achmad Tharmizi (2013: p.177) mengatakan "Android merupakan suatu software (perangkat lunak) yang digunakan pada mobile device (perangkat berjalan) yang meliputi sistem operasi, middleware dan aplikasi inti". Android menurut Satyaputra dan Aritonang (2014: 2) adalah sebuah sistem operasi untuk smartphone dan tablet. Sistem operasi dapat diilustrasikan sebagai jembatan antara piranti (device) dan penggunaannya, sehingga pengguna dapat berinteraksi dengan device-nya dan menjalankan aplikasi-aplikasi yang tersedia pada device. Referensi Arif Akbarul Huda (2013: p.1-5) berpendapat mengenai Android merupakan sistem operasi berbasis Linux yang khusus untuk perangkat bergerak seperti smartphone atau tablet.

Game adalah kata berbahasa Inggris yang berarti permainan atau pertandingan, atau bisa diartikan sebagai aktifitas terstruktur yang biasanya dilakukan untuk bersenang-senang. Menurut Anggra (Zulfadli Fahrul Rozi, 2010:6) game atau permainan adalah sesuatu yang dapat dimainkan dengan aturan tertentu sehingga ada yang menang dan ada yang kalah, biasanya 
dalam konteks tidak serius dengan tujuan refreshing.

Game edukasi adalah permaian yang dirancang atau dibuat untuk merangsang daya pikir termasuk meningkatkan konsentrasi dan memecahkan masalah (Handriyantini, 2009). Game Edukasi adalah salah satu jenis media yang digunakan untuk memberikan pengajaran, menambah pengetahuan penggunanya melalui suatu media unik dan menarik. Jenis ini biasanya ditujukan untuk anak- anak , maka permainan warna sangat diperlukan disini bukan tingkat kesulitan yang dipentingkan. game edukasi adalah salah satu bentuk game yang dapat berguna untuk menunjang proses belajarmengajar secara lebih menyenangkan

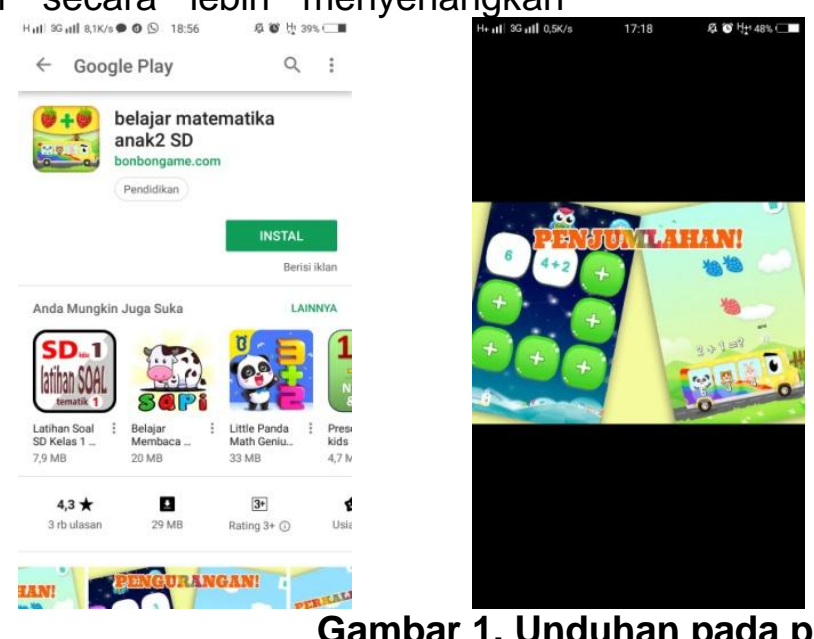

dan lebih kreatif, dan digunakan untuk memberikan pengajaran atau menambah pengetahuan penggunanya melalui suatu media yang menarik.

Penerapan game edukasi menggunakan smartphone Pada mata pelajaran matematika bagi siswa sekolah dasar adalah menggunakan handphone ataupun tablet yang memiliki Sistem operasi Android dengan Layar multitouch. Adapun pengguna dapat mudah mengunduh aplikasi pada play store. Pada play store dapat dituliskan pada menu pencarian yaitu. Selanjutnya untuk diunduh aplikasi tersebut. Berikut ini implementasi dari aplikasi game edukasi dalam pembelajaran matematika berbasis android:

Gambar 1. Unduhan pada playstore

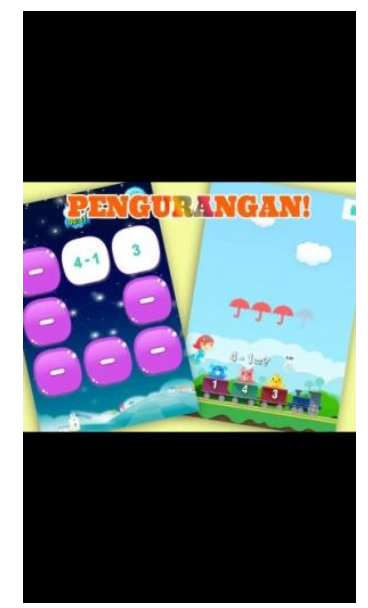

Aplikasi dapat diunduh pada play store. Setalah laman play store di klik pada pencarian matematika kelas $5 \mathrm{SD}$, muncul seperti gambar di atas. Maka tinggal dilaksanakan proses install pada Handphone atau tablet lalu aplikasi siap untuk dioperasikan.

1. Install pada Handphone atau tablet

2. Operasikan aplikasi

Pembelajaran penjumlahan dan pengurangan yang dilakukan guru adalah dengan menggunakan metode dril. Metode yang melibatkan guru secara aktif dalam poses pembelajaran dan siswa menerima materi yang diberikan guru tanpa mempunyai inisiatif mencari dan menemukan sendiri pengetahuan dan ketrampilan yang mereka butuhkan. Selain itu, guru hanya memberikan tugas dan pekerjaan rumah pada siswa. Guru tanpa menggunakan media pembelajaran yang menarik dalam menyampaikan materi penjumlahan dan pengurangan. Pada era milenial saat ini banyak media yang dapat digunakan dalam pembelajaran khususnya matematika. Meskipun guru sudah menerapkan metode dril disertai dengan pemberian tugas, tetapi hasil yang didapatkan belum sesuai dengan yang diharapkan.

Guru belum mencoba penerapan game dalam pembelajaran. Melalui game, pembelajaran yang tepat dapat mengaktifkan siswa atau (student 
centered). Penyebabnya selain mementingkan penuntasan materi yaitu guru belum mengetahui inovasi proses pembelajaran kekinian. Walaupun pada zaman komputerisasi saat ini banyak media atau media game dalam pembelajaran yang dapat mengaktifkan siswa. Pada kenyataaannya guru hanya monoton menggunakan satu metode pembelajaran. Metode yang diterapkan telah diyakini guru dapat memberikan hasil yang baik untuk siswa. Keyakinan tersebut tidak sesuai kenyataan yang terjadi di kelas II SD PB Sudirman Jakarta Timur. Sehubungan dengan permasalahan tersebut di atas, pemanfaatan game edukasi pembelajaran matematika, pada siswa kelas II SD PB Sudirman dalam pembelajaran Matematika merupakan suatu kebutuhan yang sangat mendesak untuk dilakukan.

\section{METODE PENELITIAN}

Penelitian ini dilakukan di SD PB Sudirman Kecamatan Pasar Rebo Kota Jakarta Timur. Penelitian ini menggunakan desain eksperimental. Dengan demikian ada perlakuan terhadap objek penelitian. Hal ini sesuai dengan tujuan penelitian yaitu menyelidiki ada tidaknya perbedaan setelah adanya perlakuan yang berbeda terhadap kelompok pembelajaran dengan media pembelajaran matematika berbasis android, media gambar, dan kelompok pembelajaran tanpa media. Desain eksperimental yang digunakan adalah Randomized Pretest-Posttest Control Group Design (Campbell \& Stanley, 1996: 13). Dalam desain ini terdapat tiga kelompok yaitu dua kelompok eksperimen dan satu kelompok kontrol kemudian masing-masing diberikan pretes dan postes. Pada kelompok eksperimen diberikan perlakuan, sedangkan kelompok kontrol tidak. Tes kemampuan menyelesaikan soal pecahan awal (pretes) diadakan pada kelompok eksperimen dan kelompok kontrol. Kemudian dilakukan uji perbedaan rerata kemampuan menyelesaikan soal pecahan antara ketiganya untuk memperoleh kondisi awal yang sama. Pada akhir perlakuan dilihat perbedaan pencapaian pretes dan postes kelompok eksperimen $\left(\mathrm{O}_{2}-\mathrm{O}_{1}\right.$ dan $\left.\mathrm{O}_{4}-\mathrm{O}_{3}\right)$ dan perbedaan pretes dan postes kelompok kontrol $\left(\mathrm{O}_{6}-\mathrm{O}_{5}\right)$, kemudian postes yang diajarkan dengan menggunakan game edukasi pembelajaran matematika dibandingkan dengan postes yang diajarkan dengan tanpa media $\left(\mathrm{O}_{2}-\mathrm{O}_{4}-\right.$ $\mathrm{O}_{6}$ ). Metode pengumpulan data menggunakan tes. Teknik analisis data yang digunakan adalah Anava yang dilanjutkan dengan uji Scheffe.

\section{PEMBAHASAN}

Pada bagian ini dikemukakan pembahasan terhadap hasil-hasil penelitian yang meliputi: perbedaan keefektifan game edukasi pembelajaran matematika dalam Pembelajaran pecahan siswa SD PB Sudirman Jakarta Timur. Berdasarkan hasil analisis data, telah terbukti bahwa terdapat perbedaan yang signifikan keefektifan media pembelajaran matematika berbasis android dan tanpa media dalam Pembelajaran penjumlahan dan pengurangan siswa SD PB Sudirman. Hal ini ditunjukkan dengan hasil Analisis Variansi $\mathrm{F}_{\text {hitung }}=$ 6,211 lebih besar daripada $F_{\text {tabel }}=3,02$ yang berarti signifikan. Jadi, dapat disimpulkan bahwa terdapat perbedaan keefektifan game edukasi pembelajaran matematika dan tanpa media dalam pembelajaran penjumlahan dan pengurangan.

Perbedaan keefektifan game 
edukasi dalam pembelajaran matematika berbasis siswa di SD PB Sudirman. Dari hasil analisis data, telah terbukti bahwa ada perbedaan yang signifikan keefektifan game edukasi pembelajaran matematika berbasis android dan tanpa game. Selanjutnya terbukti bahwa diperoleh probabilitas sebesar 0,024 lebih kecil dari taraf signifikansi yang ditetapkan yaitu 0,05 , maka $H_{0}$ ditolak $H_{1}$ diterima, sehingga dapat disimpulkan bahwa terdapat perbedaan keefektifan game edukasi pembelajaran matematika berbasis android dan tanpa media dalam pembelajaran pecahan. Batas bawah interval konfidensi bernilai positif sebesar 0,9137 dan batas atas bernilai positif sebesar 19,0813,
Selanjutnya terbukti bahwa diperoleh probabilitas sebesar 0,005 lebih kecil dari taraf signifikansi yang ditetapkan yaitu 0,05 , maka $H_{0}$ ditolak $H_{1}$ diterima, sehingga dapat disimpulkan bahwa terdapat perbedaan keefektifan game edukasi pembelajaran matematika dan tanpa game dalam Pembelajaran penjumlahan dan pengurangan SD PB Sudirman Jakarta Timur. Batas bawah interval konfidensi bernilai positif sebesar 3,1246 dan batas atas bernilai positif sebesar 21,3232, maka dapat disimpulkan bahwa media pembelajaran matematika berbasis android lebih efektif dibandingkan tanpa media.

\section{SIMPULAN}

Berdasarkan analisis data dan pembahasan, maka penelitian dapat disimpulkan bahwa terdapat perbedaan yang signifikan keefektifan game edukasi pembelajaran matematika berbasis android dalam Pembelajaran penjumlahan dan pengurangan SD PB Sudirman. tidak terdapat perbedaan yang signifikan tanpa media dalam Pembelajaran penjumlahan dan pengurangan di SD PB Sudirman. Pembelajaran penjumlahan dan pengurangan di SD PB Sudirman dengan game edukasi dalam pembelajaran matematika berbasis android paling efektif dibandingkan tanpa media.

Hasil penelitian ini secara praktis
dapat digunakan sebagai bahan
pertimbangan bagi para guru, terutama
guru matematika agar lebih
memperhatikan kebutuhan siswanya.
siswa memerlukan pendekatan belajar
yang dapat melibatkan siswa secara aktif,
sehingga pembelajaran yang dilakukan
dapat bermakna bagi siswa. Dengan
diketahui bahwa pemanfaatan game

edukasi pada pembelajaran matematika efektif diterapkan. Maka guru dapat memanfaatkan game edukasi ini sebagai alternatif dalam penjumlahan dan pengurangan.

Untuk kesempurnaan penelitian ini, disarankan kepada peneliti untuk mengadakan penelitian lanjutan dengan melibatkan aspek lain seperti: motivasi, sikap, intelegensi, minat, gaya belajar, lingkungan belajar, latar belakang sosial ekonomi, kondisi masyarakat dan alam dengan kajian pustaka yang lebih mendalam. Di samping itu, disarankan juga untuk memperbanyak jumlah populasi dan sampel penelitian, serta menambah waktu pelaksanaan penelitian. Game edukasi ini masih dapat dikembangan dengan mengupdate Materi matematika kelas II dan Soal latihan yang lebih banyak dan variatif. Media Pembelajaran ini dapat dikembangkan dengan menambahkan fitur-fitur unik dan warna yang lebih menarik, hal ini sesuai dengan perkembangan siswa SD. 


\section{DAFTAR PUSTAKA}

Arif Akbarul Huda. (2013). Live Coding! 9 Aplikasi Buatan Sendiri. Yogyakarta: ANDI

Anggra. (2008). Memahami Teknik Dasar Pembuatan Game Berbasis Flash, Yogyakarta: Gava Media

Asri C. Budiningsih. (2003). Belajar dan pembelajaran. Yogyakarta.UNY

Berk, L. E (2012). Development throught the lifespan $\left(4^{\text {th }} \mathrm{ed}.\right)$. (Terjemahan Daryanto). Boston: Pearson education, Inc. (Buku asli diterbitkan tahun 2007).

BSNP. (2006). Standar untuk satuan pendidikan dasar dan menengah: standar kompetensi dan kompetensi dasar SD/MI. Jakarta: BSNP

(2007).Standar proses untuk satuan pendidikan dasar dan menengah. Jakarta: BSNP

Campbell, Donald T., \& Stanley, Julian C. (1966). Experimental and quasiexperimental designs for research. Rand Menally \& Company Chicago.

Chrisnaji, Banindra Yudha. (2014). Peningkatan Kepercayaan Diri Dan Proses Belajar Matematika Menggunakan Pendekatan Realistik Pada Siswa Sekolah Dasar. Jurnal Prima Edukasia, Volume 2 - Nomor 1,2014

(2018). Peningkatan Motivasi Belajar Mahasiswa Pada Mata Kuliah Konsep Dasar Matematika Melalui Pendekatan Contextual Teaching And Learning. Jurnal Pendidikan Dasar Volume 9, Nomor 1, 2018, Pascasarjana Universitas Negeri Jakarta

Dyah Anungrat Herzamzam (2018). Peningkatkan Minat Belajar Matematika Melalui Pendekatan Matematika Realistik (PMR) Pada Siswa Sekolah Dasar, Jurnal Visipena Volume 9, Nomor 1, 2018, STKIP Bina Bangsa Getsempena Banda Aceh

Nitko, A.J \& Brookhart, S.M. (2007). Educational assesment of student. Upper Saddle Rive, New Jersey: Pearson eduactional, Inc

Gravemeijer, K. (1994). Developing Realistic Mathematics Education. Utrecht: Freudenthal Institute.

Haylock, D \& Thangata, F.(2007). Key concept in teaching primary mathematic. London: SEGE Publication

Hamzah. B.Uno. (2009). Model pembelajaran (menciptakan proses belajar mengajar yang kreatif dan efektif). Jakarta: Bumi Aksara.

Handriyantini, Eva. (2009). Permainan Edukatif (Educational Games) Berbasis Komputer untuk Siswa Sekolah Dasar. e-Indonesia Invitiative 2009 (ell2009). 
D. A. Herzamzam / DWIJA CENDEKIA: Jurnal Riset Pedagogik 2 (2) (2018) 17-25

Heruman.(2008).Model Pembelajaran Matematika di Sekolah Dasar. Bandung: PT Remaja Rosdakarya

Satyaputra dan Aritonang. (2014). Beginning Android Programming with ADT Budle. Jakarta: Elex Media Komputindo
Sugeng Purwantoro, Heni Rahmawati, dan Achmad Tharmizi. (2013). Mobile Searching Objek Wisata Pekanbaru Menggunakan Location Base Service (LBS) Berbasis Android. Jurnal. Politeknik Caltex $\begin{array}{llll}\text { Riau. (Vol } & 1 & \mathrm{hlm} & 177) .\end{array}$ 